\title{
In the Importance of EFL Learners' writing Skill: Is there any Relation between Writing Skill and Content Score of English Essay Test?
}

\author{
Monirosadat Hosseini ${ }^{1, \star}$, Mohamad Ehsan Taghizadeh ${ }^{2}$, \\ Mohamad Jafre Zainol Abedin ${ }^{3, * *}$, Elham Naseri ${ }^{4}$ \\ ${ }^{1}$ School of Educational Studies, University Sains Malaysia, 11800 Penang, Malaysia \\ 2Department of Psychology, Payame Noor University, PO BOX 19395 - 3697, Tehran, Iran \\ ${ }^{3}$ Department of Psychology, School of Educational Studies, University Sains Malaysia, \\ 11800 Penang, Malaysia \\ ${ }^{4}$ Department of Psychology, Payame Noor University, PO BOX 19395 - 3697, Tehran, Iran \\ *,**E-mail address: Ho.mahmonir@yahoo.com , jafre@usm.my
}

\begin{abstract}
Achievement test scores are used to diagnose strengths, weaknesses, and a basis for awarding prizes, scholarship, or degrees. They are also used in evaluating the influences of course of study, teachers, teaching methods, and other factors considered to be significant in educational practice. Still, sometimes there is a gap in the score of essay tests and the existing knowledge of examinees. In the present study, the relationship between writing skill and the academic achievement of Iranian EFL students was examined to find a logical connection between them. The results of four final exams as content scores were examined and scored again in term of writing ability in analytical scoring scheme according to IELTS criteria. Then the average of two sets of scores calculated by two raters was compared with content scores of the same tests. The results showed that correlation between content score of all students and their writing skills is meaningful at 0.01 level of significance. The results showed that there is a strong relationship between EFL students' degree of content score and their writing skill.
\end{abstract}

Keywords: essay tests; content score; writing skill; IELTS criteria; academic achievement

\section{INTRODUCTION}

For finding out if students can sort through a large body of information, comprehend what is important, and explain why it is important, essay exams are a useful tool (Trimmer, 2004). In addition, studies on language testing procedures and strategies aim at determining if test takers complete the given task in a way that relates to the constructs or processes in the target language use context (Ascensión, 2005; Cohen \& Upton, 2007; Plakans, 2008, 2009).

Most importantly, test developers try to determine if test takers actually are doing what it is assumed they going to do to deduce the language products and scores obtained from particular tests. If it is true, we can say that the processes used by test takers to come up to various test tasks are a validity-related concern (Bachman, 2002, 2004; Cohen, 2007). While 
most processes examined the test takers' construct thinking through answering the constructresponse items, the approaches to performance-based task, such as reading-to-write, have still remained relatively unexplored. According to Spivey $(1984,1990,1997)$, students in writing essay tasks use a meaning-making process that involves organizing ideas of what they understand from the passages, selecting from texts, and integrating ideas based on inferences from them. Then in writing, they use cohesion markers to make connections within and across texts to communicate their ideas while writing.

Plakans (2008), in comparing processes in reading-to-write and writing-only tasks, found a great difference across writers on the reading-to-write tasks, but more pre writing planning are elicited by the writing-only tasks.

Similarly, Ascención (2005, 2008), in her studies on two reading-to-write tasks: a summary task and a reflective essay, confirmed that the existence of discourse synthesis is an underlying construct. However, the reflective essay elicited more cognitive operations than did the summary. These studies have provided a basis for understanding writing processes employed in integrated writing assessment by incorporating reading into the writing process, comparing writer processes across tasks and using discourse synthesis as an underlying construct.

To improve the reading comprehension of students and enhance the quality of students' knowledge in any field of study, it is necessary to learn English as a prerequisite for any subject of study. This is why each student, in any field of study, should pass two or three ESP courses in non-English language countries such as Iran. English students, however, are more eager to learn how to read the English texts as well as their own mother tongue. So, students' reading comprehension becomes better than their writing skills among all English students in Iran. However, in spite of their high competence in reading skills, their scores in essay writing and content score are not what have been expected among English students. The reason may be the lack of writing skill or little writing competence in essay tests. One of the most serious problems that Iranian EFL students face in their field of study is their inability to communicate and handle English after graduating from university. This is due to their weaknesses in English proficiency which influence their academic success, especially in writing skill which is necessary to convey their knowledge.

In addition, the ability to write well can have a profound impact on our lives. Writing can be an art, but it is the task of the artist to create the masterpiece. Without the competency and practice of basic writing skills, neither proficient works of written art can be fictional nor can any lives be influenced (Currier, 2008).

In discussing the importance of writing to learning, Suleiman (2000) asserts that "writing is a central element of language, any reading and language arts program must consider the multidimensional nature of writing in instructional practices, assessment procedures, and language development." (p. 155). Examining this multidimensional nature of the writing process helps in comprehending of writing fundamentals.

Hand et al. (2007, p. 34) states that: "You can have the greatest technical skills in the world, but without solid communication skills, who will know and who can understand?" This raises a concern about the progression of ESL instructions from oral conversations to written prose.

Considering the enormous power of words to influence and persuade others, before a student graduates from high school, a proficient writing instruction should be established, which is becoming increasingly insufficient of academics focusing mainly upon only final course test (Currier, 2008). On the other hand, course tests are the most widely accepted means for determining academic achievement of students. However, there are ways to assess 
a students' academic and general success (Currier, 2008). Although there seems to be no tendency to ignore the importance of such tests, there needs to be more emphasis on writing during the terms of study more than before.

The present study aims at focusing not only on the assessment of students' academic knowledge (reading comprehension), but also on their ability to express their knowledge on paper sheet by assessing their writing ability based on IELTS criteria. We used IELTS criteria because in addition to be one of the most popular ESL tests throughout the world, it is also distinctive among other tests in terms of the claim of assessing "English as an international language", demonstrating a recognition of the expanding status of English. This study aimed at comparing the content scores of EFL students with their writing skills to find a logical relationship between them. The intent of the present study is therefore, to examine the strength of relationship between writing skill and Iranian EFL students' academic achievement according to discourse synthesis.

\section{BACKGROUND}

Strong writing skills may enhance students' chances for success (Alexander, 2008). In discussing the significance of writing to learning, Suleiman (2000) also stresses that writing is an essential factor of language. Any reading and language curriculum must think about the multidimensional nature of writing in instructional practices, evaluation procedures, and language development.

One major implication of the use of writing purposes to develop the writing construct is that there may be processing models for each distinct level of writing purpose (Lee \& Kantor, 2005).

When a process is unfamiliar, it requires conscious attention and sometimes has to be performed step by step, little by little, and when we become more skilled at the process, it gets automatized, demanding fewer cerebral resources. Profettis (1985) verbal efficiency theory (or bottleneck hypothesis) finds the solution in the Working Memory (WM) capacity. According to Profettis (1985) verbal efficiency theory (or bottleneck hypothesis), where encoding and decoding (as in writing vs. reading) are slow; it results in focusing on local (small scale) rather than global (text-wide) memory relations.

Stanovich's Interactive-Compensatory hypothesis seeks for a trade-off between topdown and bottom-up processing to arrive at maximum efficiency in linguistic processing.

Drawing on already existing research and theory in the field of writing, it is possible that the purpose of the hierarchy outlined previously could be related to the arguments of Bereiter and Scardamalia (1987) that there may be more than one writing process. This argument would suggest that, as writing purpose generally involves greater writing complexity and performance demands, the actual writing processes alter somewhat in their component emphases and capacity constraints. This is the basic theory proposed by Bereiter and Scardamalia with their models of knowledge telling and knowledge transforming (Kirsch \& Mosenthal, 1990).

In the L2 writing literature, surprisingly little research has been conducted to investigate the "simultaneous" impact of writers' background knowledge, their general language competency and content comprehension on the writing performance. Many studies in L2 writing measurement paid much attention to only the matter of topic variables. Carlson et al. (1985), Spaan (1993), Hamp-Lyons and Pochnow (1990), and Reid (1990) studied the interaction between topics and task types affecting the writers' performance, and found that topic types were important factors affecting the writers' final product. 
Stapa (2001) also reported that Malaysian students in Business departments scored significantly better when they write on a topic specific to their major than on a general topic. The findings showed that more complicated syntactical components and a more coherent rhetorical structure were produced when candidates write on a business topic.

On the other hand, whenever writing performance is elicited under time constraints, some learners may exhibit greater fluency in writing, as measured by the number of words written in a certain time period. It is important to note that such written fluency does not entail sophistication of content or accuracy of forms, but is simply "a measure of the sheer number of words or structural units a writer is able to include in their writing within a particular period of time" (Wolfe- Quintero, Inagaki, \& Kim, 1998, p. 14). This study will elucidate the extent to which the general language competency would play a role in an integrated writing test as well as the role of writers' background knowledge of the subject matter on writing performance.

\section{MATERIALS AND METHODS}

Most course materials in academic careers are examined in the form of essay tests and students should convey their understanding by writing, so writing skill plays an important role in educational success, especially for EFL students. Therefore, answering the following question may lead to a reasonable solution to the main problem of students' failure in educational career:

Is there any correlation between students' writing competency and their academic essay tests scores?

\section{PARTICIPANTS AND PROCEDURES}

A group of 155 students selected from intact group of EFL classes took part in this study. The age of the participants was between 19 and 25. The condition of academic progress for every participant is passing all academic books. Of course, as they are homogeneous in terms of English proficiency, the majority of exams are conducted in essay forms and the students should reply the questions according to the content of their given text books during an allocated time for each exam. Since the study intended to find a relation between students' content score in final exam and their writing skill, the result of four essay exams derived from four academic given text books have been analyzed again in terms of writing skill criteria. Scoring criteria play a crucial role in rater-mediated performance assessments. This is particularly evident in the case of analytic scoring methods where assessments are made in relation to each criteria designed to represent central features of the language performance under consideration. From a rater cognition perspective, scoring criteria channel the ways in which raters perceive and evaluate concrete samples of language performance and, finally, come to assign scores to examinees (McNamara, 1996; Wolfe, 1997; Lumley, 2005).

As scoring for content score was related to the academic knowledge of students, the academic rater (the teachers) did not consider writing skill criteria in terms of standard writing. Therefore, the researcher employed IELTS criteria -band score between 1 to 9 indicators- in rating writing skill, and examined respondents' writing ability independent from their academic competency. Each essay test was graded independently by two raters. In addition, to increase the reliability of rating, the researcher employed two raters separately; each of them was asked to use IELTS scoring criteria. Raters were EFL teaching assistants 
with more than five semesters of EFL teaching experience. Examinees rarely receive the lowest score level because all of them were studying as EFL in BA degree and were advanced; therefore, the writing scores were higher than 3 . When two raters' scores on an essay differ by one level, they discussed the essay to reach a consensus score. The reliability between the two sets of scores obtained by two independent raters was relatively high and we can say that we had an acceptable inter rater reliability in this study.

The content score criteria have been on the basis of objectively-scored to examine the overall knowledge of students on the content of text books. However, to score writing ability, analytical scoring has been employed. In this method of scoring, the rater employed a marking scheme which is used in scoring IELTS writing compositions.

\section{DATA ANALYSIS}

As the data of research were only test scores and the aim of study was comparing the results of one set of scores in terms of two different criteria, correlation coefficient formula was used. To detect the reliability of the data (two sets of scores obtained by two raters on one individual test), Pearson product moment was utilized.

Overall mean for each instrument were calculated. The average of two set of scores calculated by two raters was compared with content score of the same tests which has been scored by their teachers in terms of content of their text books. Then the collected data from four essay tests derived from four text books and the results of their writing scores were analyzed through SPSS computer software.

\section{RESULTS OF THE STUDY}

In this study, two sets of data were analyzed. First, the content scores of four different essay tests derived from four university textbooks, which were given to four intact groups consisting of 155 EFL students, were taken into account.

Then each essay test was rated by two raters based on IELTS rating criteria to measure the writing skill of each individual. The two sets of scores were analyzed by correlation coefficient formula to find out the relationship between them.

The aim was to see whether there is any relationship between writing skill of students and their content score. Of course, as the number of each paper test from different textbooks was different, in order to ensure the effect of each title, not only was the correlation of whole group calculated (Table 1), but also the correlation of each group was obtained separately (Tables 4 to 7 ).

In addition, the gender, as moderator variable, was considered and the correlation of each gender was also calculated for the whole group (Tables 2 and 3).

\section{INFERENTIAL STATISTICS ANALYSIS}

According to Table 1, the number of all students in this study is 155 . The observed value obtained by Pearson product moment formula, is .493 which is higher than critical value at.01 level of significance for a non-directional (two tailed) test. 
Table 1. Statistical Analysis of Whole Content Scores and the Writing Score.

\begin{tabular}{llll}
\hline & & G1 & G2 \\
\hline G1 & Pearson Correlation & 1 & $.493\left(^{* *}\right)$ \\
\hline & Sig. (2-tailed) &. & .000 \\
\hline & $\mathrm{N}$ & 155 & 155 \\
\hline G2 & Pearson Correlation & $.493(* *)$ & 1 \\
\hline & Sig. (2-tailed) & .000 &. \\
\hline & $\mathrm{N}$ & 155 & 155 \\
\hline
\end{tabular}

The result shows that the correlation between content score of all students and their writing score is meaningful and the coefficients show the strength of the correlation and the positive relationship. According to Table 2, the number of males in this study iwass 36 . The observed value obtained by Pearson product moment formula, is .515 which is higher than critical value at .01 level of significance for a non-directional (two tailed) test.

Table 2. Statistical Analysis of Males' General Content Scores and their Writing Score.

\begin{tabular}{llll}
\hline & & $\mathrm{C} 1$ & $\mathrm{C} 2$ \\
\hline $\mathrm{C} 1$ & Pearson Correlation & 1 & $.515\left(^{* *}\right)$ \\
\hline & Sig. (2-tailed) &. & .001 \\
\hline $\mathrm{N}$ & 36 & 36 \\
\hline & Pearson Correlation & $.515(* *)$ & 1 \\
\hline & Sig. (2-tailed) & .001 &. \\
\hline & $\mathrm{N}$ & 36 & 36 \\
& Note. ** Correlation is significant at the 0.01 level (2-tailed).
\end{tabular}

The result shows that the correlation between content score of males and their writing score is meaningful and the coefficient shows the strength of the correlation and positive relationship.

According to Table 3, the number of females in this study was 119 . The observed value obtained by Pearson product moment formula, was .474, which was higher than critical value at .01 level of significance for a non directional (two tailed) test. The result shows that the correlation between content score of females and their writing score is meaningful and the result number shows the strength of the correlation and positive relationship. 
Table 3. Statistical Analysis of Females' General Content Scores and their Writing Score.

\begin{tabular}{llll}
\hline & & B1 & B2 \\
\hline B1 & Pearson Correlation & 1 & $.474(* *)$ \\
\hline & Sig. (2-tailed) &. & .000 \\
\hline B2 & 119 & 119 \\
\hline & Pearson Correlation & $.474\left(^{* *}\right)$ & 1 \\
\hline & Sig. (2-tailed) & .000 &. \\
\hline & N & 119 & 119 \\
\hline
\end{tabular}

According to Table 4, the number of contrastive analysis paper tests was 44 . The observed value obtained by Pearson product moment formula, was .751 which is higher than critical value at .01 level of significance for a non directional (two tailed) test and it shows that the correlation between contrastive analysis content score and its writing skill score is meaningful and the result shows the strength of the correlation and the positive relationship.

Table 4. Correlation Between of Contrastive Analysis Content Score and the Writing Score.

\begin{tabular}{llll}
\hline & & A1 & A2 \\
\hline A1 & Pearson Correlation & 1 & $.751(* *)$ \\
\hline & Sig. (2-tailed) & $\cdot$ & .000 \\
\hline A2 & Pearson Correlation & $.751(* *)$ & 1 \\
\hline & Sig. (2-tailed) & .000 &. \\
\hline & $\mathrm{N}$ & 44 & 44 \\
\hline
\end{tabular}

According to Table 5, the number of applied teaching paper tests was 18 . The observed value obtained by Pearson Product moment formula, is .373, which is lower than critical value at .01 level of significance for a non directional (2-tailed) test. This shows that the correlation between applied teaching content score and writing score is not meaningful. 
Table 5. Correlation Between Applied Teaching Content Score and the Writing Score.

\begin{tabular}{llll} 
& & D1 & D2 \\
\hline D1 & Pearson Correlation & 1 & .373 \\
\hline & Sig. (2-tailed) &. & .128 \\
\hline D2 & Pearson Correlation & .373 & 1 \\
\hline & Sig. (2-tailed) & .128 &. \\
\hline & $\mathrm{N}$ & 18 & 18 \\
\hline
\end{tabular}

Note. Correlation is not significant at the 0.01 level (2-tailed).

According to Table 6, the number of psycholinguistic paper tests is 43 . The observed value obtained by Pearson product moment formula, is .254, which is lower than critical value at .01 level of significance for a non directional test. This shows that the correlation between psycholinguistic content score and writing score is not meaningful.

Table 6. Correlation Between Psycholinguistics Content Score and the Writing Score.

\begin{tabular}{llll}
\hline & & E1 & E2 \\
\hline E1 & Pearson Correlation & 1 & .254 \\
\hline & Sig. (2-tailed) & $\cdot$ & .100 \\
\hline & $\mathrm{N}$ & 43 & 43 \\
\hline E2 & Pearson Correlation & .254 & 1 \\
\hline & Sig. (2-tailed) & .100 &. \\
\hline & $\mathrm{N}$ & 43 & 43
\end{tabular}

Correlation is not significant at the 0.01 level (2-tailed).

According to Table 7, the number of research approach paper tests is 50 . The observed value obtained by Pearson product moment formula, is .276, which is lower than critical value at .01 level of significance for a non directional (two tailed) test. The result shows that the correlation between research approach content score and writing score is not meaningful. 
Table 7. Correlation between Research Approach Content Score and the Writing Score.

\begin{tabular}{llll}
\hline & & F1 & F2 \\
\hline F1 & Pearson Correlation & 1 & .276 \\
\hline & Sig. (2-tailed) &. & .052 \\
\hline F2 & Pearson Correlation & .276 & 50 \\
\hline & Sig. (2-tailed) & .052 & 1 \\
\hline & $\mathrm{N}$ & 50 &. \\
\hline
\end{tabular}

Correlation is not significant at the .01 level (2-tailed).

As shown the results of the analysis, the correlation coefficient of students' writing skill in essay type tests and their content scores were high and the relationship was positive and strong.

\section{DISCUSSION}

The whole problem is the small capacity of the Working Memory (WM). The whole brain is turned towards automaticity of mental processes. So that one can build sentences without much attention to lexico syntactic information as one needs to do in writing. If the process is automat zed then few demands are made upon the WM and there is capacity available for higher mental processing.

In other words, when bottom-up processing (here everything that goes below sometimes such as syntax, lexical choice, punctuation and lexico syntactic) is so hard and the brain is overloaded with it, little neutral networking is left for higher processes such as semantics and neutral connection building for knowledge.

Therefore, the authors conclude that EFL students at least need to be at the trade-off level to be able to focus on content. As far as they are slaves of the forms, the content eludes from their focus, of course, almost all teachers are to some extent inclined or mentally forced to mingle lower and higher processing flaws in the scoring and this is one of the problems in doing research similar to ours.

Another problem is finding the threshold of trade-off. In short, how much automaticity is necessary for students to shift their attention from form to content? Tan (2006) argues that when the focus is shifted from performance in a one-time high-stakes examination to continuous writing development in class, students can experiment with writing outside examination genres, and then they can benefit from the use of the process approach prescribed in their English textbook for writing. The following table shortly demonstrates some related studies done in this area. 


\begin{tabular}{cll}
\hline Researcher & Focus on & Finding \\
\hline Gay (2002) & $\begin{array}{l}\text { Developing Dimensions of } \\
\text { Written Language }\end{array}$ & $\begin{array}{l}\text { writing has been associated with } \\
\text { promoting students critical } \\
\text { thinking and learning skills }\end{array}$ \\
\hline Poock, et al. (2007) & $\begin{array}{l}\text { Using the science writing } \\
\text { heuristic in the general } \\
\text { chemistry laboratory to } \\
\text { improve students' academic } \\
\text { performance }\end{array}$ & $\begin{array}{l}\text { Expleaching in writing was } \\
\text { students' learning procedure and } \\
\text { academic achievement }\end{array}$ \\
\end{tabular}

Suleiman (2000)

The process and product of Writing skill improves reading writing comprehension ability and also restating what there is in students' mind and express them clearly

\begin{tabular}{cll}
\hline & $\begin{array}{l}\text { Examining the effect of } \\
\text { multiple writing tasks on }\end{array}$ & $\begin{array}{l}\text { Using multiple forms of writing } \\
\text { significantly supported effective } \\
\text { Hand, et al. (2007) }\end{array}$ \\
$\begin{array}{l}\text { Year 10 biology students' } \\
\text { understandings of cell and } \\
\text { molecular biology concepts }\end{array}$ & \\
\hline Tan (2006) & $\begin{array}{l}\text { Writing English Essays } \\
\text { within dominant discourses } \\
\text { in Malaysian schools }\end{array}$ & $\begin{array}{l}\text { Writing should be taught as a } \\
\text { students enjoy self-expression }\end{array}$
\end{tabular}

\section{CONCLUSIONS}

Writing skills can be major criteria towards better academic position and greater educational success. However, this good advice will be lost if students do not believe the importance of writing skills in helping them achieve academic mastery. The present study results can convince and help them to find a way to improve their writing ability. There may be students with a high degree of knowledge and they may know the answer of a question of an essay test, but conversely obtain a low mark from that test because they cannot express their knowledge as the result of writing weakness. Thus it is very important for English or any other language students to have a strong writing ability to show his/her inner information. The finding is in line with Hansen's (2002) which states that academicians and business people view writing skill as crucial, yet increasing numbers of these professionals note a steady attrition in the writing abilities of graduates.

The finding also confirms the Alexander's (2008) belief that argues, knowledge may be power, but how one communicates his knowledge is the prerequisite for learning within society. Writing skills are the primary tools for communicating knowledge, especially in educational settings. The capacity to communicate specifically may prove to be an achievement in life chances. On the other hand, the ability to represent oneself well on paper will help him secure a job or higher educational chances after graduation, as one will be more 
attentive to the significance of the quality of the presentation of his written work (like a resume and cover letter of a proposal). The way of writing, according to Tan (2010), says a lot about him as a person. He also states that presentation, clearness, and professionalism can help differentiate a person from the others. Further, in the workplace or academic contexts, good writers are exceedingly prized (since so few people can write well). Writing well, thus, opens the door to progress in almost any field a person might opt for in the future.

\section{References}

[1] Alexander M., Good writing leads to good testing. 2008, Retrieved from Http://www.stickyminds.com/sitewide.asp?ObjectId=3391\&Function=edetail\&ObjectTy $\mathrm{pe}=\mathrm{ART}$ on March 262012.

[2] Ascención Y., Validation of reading-to-write assessment tasks performed by second language learners. Unpublished doctoral dissertation, Northern Arizona University, Flagstaff, 2005.

[3] Ascención Y., Journal of English for Academic Purposes 7 (2008) 140-150.

[4] Bachman L., Language Testing 19(4) (2002) 453-476.

[5] Bachman L., Statistical analysis for language assessment. Cambridge, UK: Cambridge University Press, 2004.

[6] Bereiter C., Scardamalia M., The psychology of written composition. Essay on research and pedagogy. Norwood, NJ: Ablex, 1987.

[7] Carlson S., Bridgeman B., Camp R., Waanders J., Relationship of admission test scores to writing performance of native and nonnative speakers of English. TOEFL Research Report No. 19. Princeton, NJ: Educational Testing Service, 1985.

[8] Cohen A. D., Language Assessment Journal 3(4) (2007) 307-331.

[9] Cohen A. D., Upton T. A., Language Testing 24(2) (2007) 209-250.

[10] Currier D., Essay on the importance of writing - need feedback please. Asian ESL Journal. Retrieved from Gloria, Essay Writing Feedback/EssayForum.com on 8/17/2010 Journal 80 (2008) 183-199.

[11] Gay G., Developing Dimensions of Written Language. Adaptive Technology Resource Centre. Retrieved March 26, 2002.

[12] Hamp-Lyons L., Prochnow S., Journal of Second Language Writing 3 (1990) 74-93.

[13] Hand B., Hohenshell L., Prain V., Instructional Science 35(4) (2007) 343(31).

[14] Hansen R., Hansen K., Retrieved from Enhance MyWriting.com on 8/19/2010, a subsidiary of EmpoweringSites.com -- DeLand, 2008, FL 32720 Home Page: http://www.empoweringsites.com/

[15] Kirsch I., Mosenthal P., Journal of Reading 34 (1990) 552-558.

[16] Lee Y., Kantor R., Dependability of new ESL writing test scores: Tasks and alternative rating schemes (TOEFL Monograph Series no. 1). Princeton, NJ: ETS, 2005. 
[17] Lumley T., Assessing second language writing: The rater's perspective. Frankfurt: Lang, 2005.

[18] McNamara T. F., Measuring second language performance. London: Longman, 1996.

[19] Plakans L., Assessing Writing 13 (2008) 111-129.

[20] Plakans L., Second language writing and reading-to-write assessment tasks: A process study. Unpublished Doctoral Dissertation, The University of Iowa, Iowa, IA, 2009.

[21] Poock J. R., Burke K. A., Greenbowe T. J., Hand B. M. Journal of Chemical Education 9 (2007) 1371.

[22] Reid J., Responding to different topic types: A quantitative analysis from acontrastive rhetoric perspective. Second language writing. New York, Cambridge University Press, 1990, pp. 191-210.

[23] Spaan M., The effect of prompt in essay examinations. In Douglas, D. \& Chapelle, C., editors, A new decade of language testing research. Alexandria, VA: TESOL Publications, 1993, pp. 98-122.

[24] Spivey N., Discourse synthesis: Constructing texts in reading and writing. Outstanding Dissertation Monograph. Newark, DE: International Reading Association, 1984.

[25] Spivey N., Written Communication 7(2) (1990) 256-287.

[26] Spivey N., The constructivist metaphor: Reading, writing, and making of meaning. San Diego, CA: Academic Press, 1997.

[27] Suleiman M. F., The process and product of writing: Implications for elementary school teachers. ERIC Digest, ERIC Identifier ED 442299, 2000.

[28] Tan K. E., Asia Pacific Journal of Educators and Education (Journal of Educators and Education) (2006) 23-45.

[29] Tan P., A Justification in writing an essay. The Asian EFL Journal. (2-10) (2010) 343.

[30] Trimmer J. F., Writing with a Purpose. 14th ed., New York, Houghton Mifflin Company, 2004.

[31] Wolfe-Quintero K., Inagaki S., Kim H-Y., Second language development in writing: Measures of fluency, accuracy and complexity. (Technical Report No. 17). Honolulu: Second Language Teaching and Curriculum Center, University of Hawai at Manoa, 1998. 